\title{
Analysis of Planning and Procurement Management of Health Equipment in Jeneponto Regency
}

\author{
La Ode Ashan Habibi ${ }^{*}$, Indar $^{2}$, Anwar $^{3}$, Muhammad Alwy Arifin ${ }^{2}$, Amran Razak $^{2}$, Stang $^{4}$ \\ ${ }^{\mathrm{T}}$ Master Program in the Department of Health Policy and Administration, Faculty of Public Health, Hasanuddin \\ University, Indonesia \\ ${ }^{2}$ Department of Health Administration and Policy, Faculty of Public Health, Hasanuddin University, Indonesia \\ ${ }^{3}$ Department of Environmental Health, Faculty of Public Health, Hasanuddin University, Indonesia \\ ${ }^{4}$ Department of Biostatistics, Faculty of Public Health, Hasanuddin University, Indonesia
}

\section{*Corresponding Author}

La Ode Ashan Habibi

\section{Article History}

Received: 05.07.2020

Accepted: 14.07.2020

Published: 21.07.2020

\begin{abstract}
The importance of asset management in the Department of Health in achieving optimal health services in Puskesmas, the asset management process in the form of medical devices needs to be monitored to find out weaknesses and strengths in the implementation of its operations. This study aims to analyze how the planning and procurement of medical devices in the Jeneponto District Health Office. This research is a qualitative research with indepth interview method. The number of research subjects were 7 informants selected by purposive sampling technique. The data is analyzed through three stages namely data reduction, data presentation and conclusion drawing, validity testing using source triangulation techniques and theory. The results showed that in the planning of medical devices according to procedures but not supported by medical equipment calibration budget, procurement for medical devices was in accordance with procedures but there was no stock of medical devices available in the distributor / distributor resulting in a medical device vacancy. It is recommended to the health department to increase the budget for planning the maintenance of medical devices that will be calibrated and in the procurement of goods should ensure the availability of medical devices in the health department so that they can be distributed and anticipate the emptiness of medical devices in health centers by providing a Buffer Stock.
\end{abstract}

Keywords: Planning, Procurement, medical devices, Health Service.

\section{INTRODUCTION}

Medical devices are instruments, apparatus, machines and / or implants that do not contain drugs that are used to prevent, diagnose, cure and alleviate diseases, treat sick people, restore health to humans, and / or form structures and improve bodily functions [1]. At present, it is almost impossible to provide health services without medical devices [2]. Considering the availability of medical devices is so important in the efforts of health services, it is necessary to have logistics management of medical devices to maintain quality in accordance with the standards in accordance with the classification [3]. The importance of asset management in the Department of Health in achieving optimal health services in Puskesmas, the asset management process in the form of medical devices needs to be monitored to find out weaknesses and strengths in the implementation of its operations.

The Jeneponto District Health Office is a work unit that supervises 19 puskesmas from 12 sub-districts in Jeneponto. In order to achieve optimal utilization of assets, the health office needs to manage its assets, especially the puskesmas assets which need optimal supervision from the health office. It aims to maintain and monitor the value of assets that are expected to provide results in accordance with the objectives of the SKPD which can also reduce the risk of loss.

Copyright @ 2020: This is an open-access article distributed under the terms of the Creative Commons Attribution license which permits unrestricted use, distribution, and reproduction in any medium for non commercial use (NonCommercial, or CC-BY-NC) provided the original author and source are credited. 
In addition, this management can also facilitate budgeting and avoid over-buying in meeting the supply of goods. With asset management, the Health Service can also create risk management where risk management is a structured and systematic process of identifying, measuring, mapping, developing alternative risk management and controlling risk management [4].

The regional government must be able to manage regional assets owned properly and accountably. So that they are able to provide fair opinions without exceptions (WTP). However, the Jeneponto Regency Government needs to prove whether the asset management is in accordance with technical guidelines that have been regulated based on government regulations. Despite the various efforts made by the local government to improve the performance of the management of regional assets such as the holding of technical training for all employees in charge of the management of regional assets, especially the Department of Health, which is carried out programmatically every year. The purpose of this study was to analyze how the management of planning and procurement of medical devices in the Jeneponto District Health Office.

\section{MeTHODS}

This research uses a qualitative research method with indepth interview method. Informants in this study are to the Finance and Asset Section, Planning Sub-Section, Pharmacy and Medical Devices Section, Health Service Goods Manager, Health Service Maintenance and Calibration Section, Health Center Head and Health Center Goods Manager. Analysis through three stages, namely data reduction, data presentation and conclusion drawing, validity testing using source triangulation techniques and theory

\section{RESULTS}

\section{Planning}

Hierarchically responsible starts from planning at the puskesmas level, the head of the puskesmas (Community Health Center) and KTU (the head of the administration section) who inventory the needs of the medical devices and then submit them to the health service planning department. This is consistent with the results of the interview as follows:

"The planning of medical devices refers to PP no 27 of 2014 in accordance with annual needs". KL, 45 Yrs

"Planning of medical devices for puskesmas in accordance with the needs and regulations submitted to the health office". JL, 52 Yrs

"The planning of medical devices in the health center follows the format in accordance with the regulation of the Health Minister provided by the health department". SYR, 50 Yrs

"The need for health equipment in the Puskesmas follows the format given by the DHO according to the Permenkes" SR, 51 Yrs

The selection of medical devices is based on the priority scale of the head of the drug section and medical devices based on the proposed needs of each puskesmas who follow the technical guidelines for DAK activities to procure medical devices. This is consistent with the results of the interview as follows:

"The need for medical equipment from the puskesmas is then submitted to the health department through the field of pharmaceutical services and the medical and medical devices dissection.

"The need for medical devices for puskesmas to conduct a button-up system starts from the poskesdes, pustu and puskesmas then the puskesmas goods manager recapitulates the need for medical devices to be reported to the pharmaceutical service and health department in the drug and medical devices for procurement". JL, 52 Yrs

"According to the priority needed by the puskesmas, especially medical devices used in patient services every day, then the treasurer of the assets recapitulates the needs of the puskesmas health equipment which will later be submitted to the health office for procurement". SYR, 50 Yrs

"The need for medical devices in accordance with the request of the pustu, poskesdes, polindes and puskesmas is then submitted to the treasurer of the assets of the puskesmas and a request format for the health department is made based on an analysis of the need for medical devices". SR, 51 Yrs

Determination of the number of medical devices must be in accordance with the existing budget based on the DAK (Special Allocation Fund). This is consistent with the results of the interview as follows:

"Medical device budgeting consists of DAK funds and cigarette tax revenue sharing, sub-funding is better aware of funds for medical devices, DAK funds for medical devices around 90\%". CR, 36 years old 
Table-1: Planning Flow

\begin{tabular}{|c|c|c|}
\hline \multicolumn{3}{|c|}{ Activity } \\
\hline $\begin{array}{c}\text { Head of Community } \\
\text { Health Center }\end{array}$ & $\begin{array}{l}\text { Head of the medical } \\
\text { equipment section }\end{array}$ & Management \\
\hline \multirow[t]{3}{*}{$\begin{array}{l}\text { Arranging medical } \\
\text { needs }\end{array}$} & \multicolumn{2}{|c|}{$\begin{array}{l}\text { Determine the } \\
\text { type of medical } \\
\text { needs }\end{array}$} \\
\hline & $\begin{array}{r}\text { Deter } \\
\text { number } \\
\text { de }\end{array}$ & $\begin{array}{l}\text { nine the } \\
\text { of medical } \\
\text { vices }\end{array}$ \\
\hline & $\begin{array}{l}\text { Recapi } \\
\text { propos } \\
\text { device }\end{array}$ & $\begin{array}{l}\text { ulation of } \\
\text { d medical } \\
\text { planning }\end{array}$ \\
\hline
\end{tabular}

Based on the table above, the flow of planning for Medical Devices in the Jeneponto District Health Office starts from the Head of the Puskesmas or KTU (Head of Administration) who compiles the needs of medical devices and then communicates with users such as doctors and nurses in the field of pharmaceutical services and medical devices, drug and medical devices dissection, then the head of the medical equipment section conducts a recapitulation making inventory of the overall medical device needs of each puskesmas to be used as a list of annual medical device needs

\section{Procurement}

There are two types of reservations, namely by way of a tender or ordered catalog. if the tender he follows the tender process and if through the catalog it can be ordered at any time. This is consistent with the results of the interview as follows:

"There are two types of orders, namely by way of tendering or ordering in the catalog. if the tender he follows the tender process and if through the catalog it can be ordered at any time ". KL, 45 Yrs

"Procurement of goods based on the Tender system". CR, 36 Yrs

Re-ordering of medical devices is usually done if the needs are not sufficient or if there are defective goods. This is consistent with the results of the interview as follows:

"Re-ordering medical devices is done if the needs are insufficient or there are defective goods, for ordinary defective goods returned immediately. KL, 45 Years Old"

"We usually do a reorder if the goods are not enough, but that rarely happens. CR, 36 Years Old"

"When there are defective goods we will order again. SY, 33 Years Old"

Goods ordered are usually on time, because they will get a $20 \%$ penalty if it is not in accordance with the specified order time. This is consistent with the results of the interview as follows:

"Every item ordered always arrives on time, delays rarely occur. CR, 36 Years Old"

"Goods ordered are usually on time. KL, 45 Years Old"

"It is rare to delay the order of goods. AA, 39 years old"

The availability of goods in the market is very sufficient, meaning that the tools needed are not hard to find. This is consistent with the results of the interview as follows:

"The availability of goods is very sufficient in the market. KL, 45 Years Old" 
"All medical devices needed are always available in the market. AA, 39 years old"

"The medical devices needed are not hard to find. CR, 36 Years Old"

It should be noted in ordering medical devices is the name of the device, specifications, brand / type, then the country of manufacture. This is consistent with the results of the interview as follows:

"Ordering medical devices must look at the specifications, brand, and country. KL, 45 Years Old"

"Equipment specifications need to be considered in ordering goods. CR, 36 Years Old"

The need for electric power in health service facilities in the Puskesmas is increasing, and there are some health equipment that have more power but the capacity of the Puskesmas electricity power is inadequate or not standard. This is consistent with the results of the interview as follows:

"The impact of using medical devices that use electricity must be supported by adequate power at the health center. SYR, 50 Years Old"

"The need for electric power in health service facilities in the Puskesmas is increasing, and there are some health equipment that have more power but the capacity of the Puskesmas is inadequate or not standard. KL, 45 Years Old"

Table-2: Procurement Flow

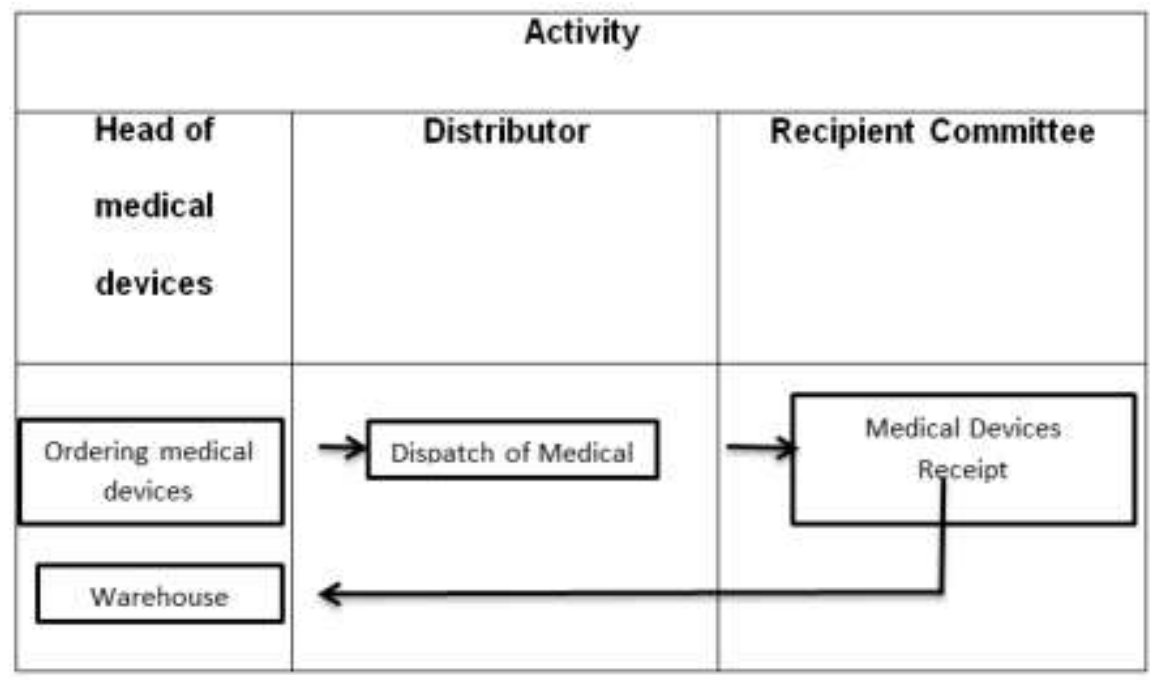

Based on the table above, the flow of procurement of medical devices in the Jeneponto District Health Office starts with the Head of the Medical Devices Section ordering medical devices at distributors and we need to know that there are two types of orders, namely by bidding or ordering in the catalog. If the tender follows the tender process and if through the catalog, the order can be ordered at any time, then the distributor passes the delivery of medical devices, is then handed to the medical equipment section and stored in the medical device storage warehouse in the Jeneponto District Health Office.

\section{DISCUSSION}

Planning (planning), namely as a rationale for the objectives and preparation of steps that will be used to achieve the goal. Planning means preparing all needs, taking into account carefully what are the obstacles, and formulating the implementation of activities that intend to achieve the goal.

Government Regulation (PP) concerning Management of State Property needs planning is an activity to determine the number and period of procurement of medical devices in accordance with the results of selection activities to ensure the fulfillment of the right type, right quantity, timely and efficient criteria.

Implementation of medical equipment planning requires equipment performance data that has been owned and the latest information on the types of medical equipment in circulation. The performance of equipment that has been obtained is obtained from the documentation of equipment utilization and maintenance data. Information on medical equipment is obtained from references from publications of manufacturers or distributors, websites, other health services that have used the equipment. The medical equipment distribution permit needs to be considered and also the 
certification / recognition information from the FDA (Food and Drug Administration) and CE, specifications, accessories, functions and reliability, maintenance, spare parts availability, prices, after sales guarantee and legality of the medical equipment distribution permit in Indonesia.

Planning certain medical equipment requires planning the needs of the room for the placement of medical equipment, medical personnel and patients as well as medical installations including electricity, medical gas, facilities. For certain equipment such as radiology equipment, radiotherapy and MRI requires specificity of room planning and medical installation in accordance with the requirements related to the type of equipment and legislation. In planning the design of rooms and medical installations taking into account the need for service development and the rapid advancement of Health technology [5].

Based on research conducted, information is obtained that the process of planning medical devices in the Jeneponto District Health Office has been systematically in accordance with the results of the interview with the head of the health service planning subdivision, saying that it is hierarchically responsible, starting from the planning of the puskesmas, kapus (head center) and KTU (Head of Administration) levels who inventory the needs of medical devices and then communicate with users such as doctors and nurses.

Medical Devices needs from Puskesmas then submitted to the Health Office through the field of pharmaceutical services and Medical Devices and Medical Devices Dissection. Head of Medical Devices Section performs a recapitulation to make inventory of the overall health equipment needs of each Puskesmas to be made a list of annual medical equipment needs, if in the fiscal year required or available funds related to medical devices are then submitted to the health service planning department to be allocated funding and financing sources to be held the puskesmas in this case is responsible for the planning of medical devices, which coordinates the pharmaceutical department and the planning department recapitulates according to a list of needs according to priority.

This is in line with the results of the study [6] in planning the determination of needs starting from the request for the needs of each installation or user recap and discussed with the leadership, service sector, supporting fields, administration and planning areas to determine priority needs. For DAK (Special Allocation Fund) funds, proposals are submitted by the medical support sector to the planning field for adjusting priorities with the medical device menu available on the DAK menu. If the priority needs are not available in the DAK menu, then they will be diverted to other needs in the DAK menu.

Similar research was also carried out by [7] about the analysis of drug planning and medical devices where the planning process in the Minahasa District Health Office was found to be incompatible with the technical guidelines for the management and procurement of public medicines and health supplies established by the Minister of Health. Based on this, the process of planning medical devices in hospitals needs to be optimized.

Similar research was conducted by [8] In terms of planning, it is carried out every year at the beginning of the period by considering the priority needs. Budgeting and procurement of medical devices have been going well, marked by having been integrated in the Asset SIM application.

Based on Government Regulation concerning the Procurement of Goods / Services is an activity to obtain Goods / Services by the Ministry / Institution / Work Unit for Regional Apparatuses / other Institutions whose process starts from the planning of needs until the completion of all activities to obtain the Goods / Services. Procurement of medical equipment supplies is an activity undertaken to obtain supplies of medical supplies from external suppliers through the purchase process of distributors or wholesalers of Alkes [9].

There are two types of reservations, namely by way of a tender or ordered catalog. if the tender he follows the tender process and if through the catalog it can be ordered at any time. Re-ordering of medical devices is usually done if the needs are not sufficient or if there are defective goods. Goods ordered are usually on time, because they will get a $20 \%$ penalty if it is not in accordance with the specified order time. The availability of goods in the market is very sufficient, meaning that the tools needed are not hard to find. That need to be considered in ordering medical devices is the name of the device, specifications, brand / type, then the country of manufacture. The need for electric power in health service facilities in the Puskesmas is increasing, and there are some medical devices that have more power but the capacity of the Puskesmas is inadequate or not standard:"

Similar research results were conducted [6] that the procurement of medical devices at the Padang Pariaman District Hospital is carried out after the list of implementation of the exit budget, the PPK registers the general procurement plan to the procurement service unit (ULP), then the commitment-making official or procurement officer selects the provider with EPurchasing through E-catalog. 
This is also in line with research [10] where the procedure for procurement of medical devices through capitation funds if medical devices have been approved, procurement is done through e-catalogs, but some Puskesmas have obtained them through third parties or partners. Medical devices financed are medical devices that support health services such as blood pressure equipment, patient beds, laboratory equipment, doctor's examinations, wheelchairs. There are health centers that buy capital expenditure tools, such as laptops. Medical devices are obtained in accordance with the DPA (Budget Implementation Document) budgeting and adjusted to the needs within one year.

Planning the procurement of medical equipment needs in the health center is one of the important things to consider so that every public health service can run well. Planning is very important to note because with good planning, the use of medical devices in health centers can be well organized in accordance with applicable procedures [11, 12].

\section{CONCLUSION}

This research concludes that in the planning of medical devices according to procedures but not supported by medical equipment calibration budget, procurement for medical devices is in accordance with procedures but there is no stock of medical devices available in the distributor / distributor, causing a medical device vacancy. It is recommended to the health department to increase the budget for planning the maintenance of medical devices that will be calibrated and in the procurement of goods should ensure the availability of medical devices in the health department so that they can be distributed and anticipate the emptiness of medical devices at the puskesmas by providing a Buffer Stock.

\section{REFERENCES}

1. Permenkes, R. I. (2018). Izin Dan Penyelenggaraan Praktik Bidan. Jakarta: Kementerian Kesehatan RI.

2. Dey, S., \& Chattopadhyay, S. (2018). Assessment of Quality of Primary Healthcare Facilities in West Bengal. International Journal of Research in Geography. 4(2):22-33.

3. Faruq, Z. H., Badri, C., \& Sodri, A. (2017). Penilaian Manajemen Peralatan Laboratorium Medis di RSUD se Provinsi DKI Jakarta. Jurnal Labora Medika. 1(1):16-20.

4. Djohanputro, B. (2013). Manajemen Risiko Korporat Terintegrasi. Jakarta: PPM Manajemen.

5. Carpman, J. R., \& Grant, M. A. (2016). Design that cares: Planning health facilities for patients and visitors (Vol. 142). John Wiley \& Sons.

6. Kenedi, J., Lanin, D., \& Agus, Z. (2018). Analisis Pengadaan Alat Kesehatan di Rumah Sakit Umum Daerah Padang Pariaman Tahun 2017. Jurnal Kesehatan Andalas. 7:9-16.

7. Rumbay, I. N. (2015). Analisis Perencanaan Obat di Dinas Kesehatan Kabupaten Minahasa. Jikmu, 5.

8. Ramadhan, F. (2020). Manajemen Logistik Alat Kesehatan di Puskesmas. HIGEIA (Journal of Public Health Research and Development). 4(2):212-222.

9. Rokx, C., Giles, J., Satriawan, E., Marzoeki, P., \& Harimurti, P. (2010). New insights into the supply and quality of health services in Indonesia. The World Bank.

10. Anggraeni, R. T., Sriatmi, A., \& Fatmasari, E. Y. (2016). Analisis Pemanfaatan Dana Kapitasi Oleh Puskesmas Dalam Penyelenggaraan Jaminan Kesehatan Nasional Di Kabupaten Purbalingga. Jurnal Kesehatan Masyarakat (eJournal). 4(4):135-144.

11. Yusliati, Y., Dupai, L., \& Lisnawaty, L. (2016). Gambaran Perencanaan Pengadaan Alat Kesehatan di Puskesmas Siompu Kabupaten Buton Selatan Tahun 2015. (Jurnal Ilmiah Mahasiswa Kesehatan Masyarakat). 1(2).

12. Bakri, H. (2018). The Planning of Community Health Center in Indonesia. European Journal of Research and Reflection in Management Sciences. 6(3):12-18. 